\title{
A REVISED CIRCUMSCRIPTION AND CLARIFICATION OF THE TAXONOMIC POSITION OF MICONIA TETRAZYGIOIDES (MELASTOMATACEAE: MICONIEAE): AN ENDEMIC TO THE MASSIF DE LA HOTTE, HAITI
}

\author{
Walter S. Judd and Lucas C. Majure \\ Department of Biology and Florida Museum of Natural History \\ University of Florida \\ Gainesville, Florida 32611-7800, U.S.A. \\ lyonia@ufl.edu; Imajure@flmnh.ufl.edu
}

\begin{abstract}
An investigation of the type material of Miconia tetrazygioides indicates that this species, only known from the type gathering (Ekman H10684), is conspecific with the recently described M. cineana. The two differ vegetatively in no significant characters, showing only a slight difference in the range in variation of leaf width, shape, apex, and margin. The species has been poorly collected, with only a total of five gatherings known, and flowers have yet to be collected; it is endemic to the Massif de la Hotte, of Haiti, occurring in rak bwa from 930 to $1300 \mathrm{~m}$. DNA nucleotide sequences indicate that the species is related to those of the M. decorticans clade, which have moderate-sized to large flowers with more or less constricted hypanthia/calyces. Traditionally, most species of the M. decorticans clade were included within Tetrazygia or Pachyanthus. In contrast the reproductive parts, e.g., calyx, hypanthium, ovary, and fruit, of M. tetrazygioides (incl. M. cineana) are quite small, and its hypanthia/calyces are not constricted, which is why it was originally circumscribed under Miconia rather than the other two mentioned genera.
\end{abstract}

\section{RESUMEN}

Una investigación del material tipo de Miconia tetrazygioides indica que esta especie, que se conoce sólo de la colección tipo (Ekman H10684), es conespecífica con la especie recientemente descrita como M. cineana. Las dos especies no se distinguen por ningún carácter significativo -solo demuestran una diferencia ligera en el rango de variación de la anchura de la hoja, en la forma, el ápice y el margen. La especie ha sido pobremente recolectada, con un total de cinco colectas, y las flores aún no se conocen. Es endémica del Macizo de la Hotte, Haití, donde crece en bosques "rak bwa" entre los 930 y 1300 m de altitud. Secuencias de ADN indican que la especie está emparentada con las especies del clado $M$. decorticans, que tienen flores moderadamente grandes a grandes con hipanto/cáliz más o menos constreñido. Tradicionalmente estas especies fueron incluidas en los géneros Tetrazygia o Pachyanthus. sin embargo, las partes reproductivas como cáliz, hipanto, ovario y fruto de M. tetrazygioides (incluyendo M. cineana) son muy pequeñas y sus hipantos/cálices no son constreñidos, por lo que fue circunscrita en el género Miconia en lugar de uno de los otros mencionados.

As part of an on-going systematic investigation of the species of Miconia (see Michelangeli et al. 2018/19) of the Caribbean region (Bécquer et al. 2008, 2017/18; Ionta et al. 2012; Judd 2007; Judd \& Ionta 2013; Judd et al. 2014a, 2014b, 2015, 2018; Majure et al. 2014, 2014/15, 2015, 2016, 2018; Michelangeli et al. 2008; Penneys \& Judd 2005; Skean et al. 2018), especially the species of the Caribbean clade (Majure et al. 2014, 2015, 2016, 2018), we had the opportunity to carefully assess the type material of the poorly understood Miconia tetrazygioides Urb. \& Ekman, i.e., Ekman H10684, which was collected in the Massif de la Hotte, Haiti (Urban \& Ekman 1929). The specimens of the type gathering differ vegetatively in almost no significant character when compared with the known specimens of M. cineana Majure et al. (Majure et al. 2014), having sometimes slightly shorter internodes, some leaves that are slightly narrower, including oblong leaves, and those with obtuse apices and entire margins (compare updated description provided here with that of M. cineana in Majure et al., 2014). All the herbarium material of M. cineana is vegetative, while the type of M. tetrazygioides has slightly immature fruits. Flowers of these plants have not been collected, and both are poorly collected (M. tetrazygioides: known only from the type; $M$. cineana: known from the type and three additional collections). Both are restricted to moist forests on limestone (rak bwa) of the Massif de la Hotte, Haiti. Applying a morphological-phenetic (Judd 1981, 2007) or diagnostic (Wheeler \& Platnick 2000) species concept, the close similarity of the herbarium material of M. tetrazygioides and M. cineana indicates that they must be treated as 
conspecific (indeed, they are essentially indistinguishable). Additionally, the lenticular, i.e., 2-ridged, twigs are likely a synapomorphy of the populations of these plants, supporting their monophyly, and thus consideration as a cladospecies (Donoghue 1985; Mishler 1985). Therefore, M. cineana is here placed in synonymy under M. tetrazygioides.

DNA nucleotide sequences of Miconia tetrazygioides (incl. M. cineana) indicate that the species is a member of the Caribbean clade (Majure et al. 2014), a major radiation in the Caribbean region (Judd \& Majure 2019; Majure et al. 2015. 2016, 2018; Michelangeli et al. 2008), and within this clade it falls within the M. decorticans clade, which includes M. aurifolia Bécquer \& Judd (= Tetrazygia aurea R.A. Howard \& W.R. Briggs), M. decorticans (Bécquer) Bécquer (= Tetrazygia decorticans Bécquer), M. elegantissima Bécquer \& Judd (= Tetrazygia elegans Urb.), M. monopleura (Urb.) Bécquer \& Majure (= Pachyanthus monopleurus Urb.), and M. urceolata Urb. (Majure et al. 2014). All of these species except M. aurifolia (which is sister to the remaining species) share the morphological apomorphy of peltate scales on the abaxial leaf surface, and M. monopleura, M. elegantissima, and M. decorticans also have peltate scales on the adaxial leaf surface (Majure et al. 2014). Miconia aurifolia has retained the ancestral indumentum condition, having ferrugineous, globular-stellate hairs abaxially. Miconia tetrazygioides likely is a cladospecies, as noted above, as it displays the putative morphological autapomorphy of lenticular stems; its monophyly is additionally supported by DNA sequence data (Majure et al. 2014). Miconia tetrazygioides also is distinctive in having small fruits (i.e., $2-2.3 \mathrm{~mm}$ across) and likely very small flowers (as indicated by the size of the calyx and hypanthium), which have non-constricted hypanthia/calyces. The other members of the $M$. decorticans clade have moderate-sized to large flowers, frequently with a constricted hypanthium/calyx, as suggested by their traditional taxonomic placement in either Pachyanthus or Tetrazygia (both of which are polyphyletic, as traditionally circumscribed). We consider that the traditional circumscription of M. tetrazygioides by Urban and Ekman (1929) in Miconia rather than Tetrazygia, likely was a result of its small fruit, with a non-constricted hypanthium, as in other species of the Caribbean clade traditionally considered to be in Miconia, such as M. tetrandra (Sw.) D. Don ex G. Don. In fact, Urban and Ekman (1929) compared M. tetrazygioides to M. chrysophylla (Rich.) Urb., which has quite small flowers and fruits.

Miconia tetrazygioides is the only member of the M. decorticans clade to occur on Hispaniola; the other species of this clade are all Cuban endemics. We thus hypothesize a long-distance dispersal event from Cuba to the Massif de la Hotte (of Hispaniola).

\section{TAXONOMIC TREATMENT}

Miconia tetrazygioides Urb. \& Ekman, Ark. Bot. 22A(17):37. 1929. TYPE: Haiti: Massif de la Hotte, western group, Les Roseaux, rocky ledge at Zanite, 1300 m, fr, 16 Sep 1928, E.L. Ekman H10684 (LECTOTYPE, here designated: S \#04-415, internet image!; ISOLECTOTYPES: K\#0000535940, internet image!, NY\#00658666, internet image!, US \#00731038!). An image of the lectotype is available at http://herbarium.nrm.se/specimens.

Miconia cineana Majure, Judd, Ionta, \& Skean. Syst. Bot. 39:910. 2014. TyPe. Haiti. Département du Sud: Massif de la Hotte, Parc National Pic Macaya, Bwa Formon, in rak bwa on hills in vicinity of Ville Formon, 930-960 m, 1 Feb 1984, veg, Judd 3939 (HоLотуPE: FLAS!; ISOTYPE: NY!).

Evergreen shrub or tree to $5 \mathrm{~m}$ tall. Young stems elliptical to lens-shaped in cross-section, with 2 sharp to blunt ridges, each extending longitudinally below the point of petiole attachment, but becoming terete with age, the indumentum of dense, ferrugineous, matted, globular-stellate hairs, 0.08-0.2 mm across, internodes 0.7-9.7 $\mathrm{cm}$ long, nodal line present. Leaves equal to slightly anisophyllous, i.e., large leaf/small leaf quotient, 1-1.6; petiole $0.8-2.6 \mathrm{~cm}$ long, the indumentum of dense, matted, globular-stellate hairs; the blade 4.5-16.7 × 1.5-5.2 $\mathrm{cm}$, ovate to elliptic or oblong, coriaceous, the apex obtuse or acute to slightly acuminate, the base cuneate or acute to obtuse or rounded, the margin plane to slightly revolute, entire or shallowly undulate to obscurely and remotely blunt-dentate, the largest teeth to $0.1 \mathrm{~mm}$; secondary veins 2 pairs, 1 conspicuous and 1 inconspicuous, acrodromous, basal, but often appearing suprabasal, the innermost pair joining midvein 2-8 mm above the leaf base, the conspicuous secondary veins spaced $1.2-5 \mathrm{~mm}$ in from margin, the inconspicuous secondary veins intramarginal to $1.5 \mathrm{~mm}$ in from margin, tertiary veins percurrent, oriented subperpendicular to 
midvein, 1-6 mm apart, connected by quaternary veins or separated by poorly developed composite inter-tertiary veins, the higher order veins reticulate, \pm obscure, the midvein, major secondary veins, and tertiary veins slightly to moderately impressed, minor secondary and quaternary veins flat to slightly impressed, remaining veins flat on adaxial surface, the midvein conspicuously raised, the major secondary and tertiary veins moderately to slightly raised, the minor secondary and quaternary veins slightly raised to flat, the higher order veins flat, \pm obscure on abaxial surface; adaxial surface green, shiny when living, appearing slightly wrinkled after drying, with scattered druse crystals, the indumentum initially of moderate, globular-stellate hairs to $0.1 \mathrm{~mm}$ across, but quickly glabrescent; abaxial surface with dense, ferrugineous to pale ferrugineous, stellate-peltate hairs, i.e., peltate scales, usually $0.1-0.2 \mathrm{~mm}$ across, occurring over both veins and lamina surface (which is thus totally obscured); hair-tuft domatia absent. Inflorescences terminal, with shoots producing numerous nodes before becoming reproductive, paniculate to elongate-paniculate cyme, $4.5-8 \mathrm{~cm}$ long, $2-5 \mathrm{~cm}$ across, with numerous flowers and 4-6 major branch pairs, with pedicel 0.6-1.9 cm long; proximal segment of lowermost inflorescence branches 9-22 mm long, with dense, matted, globular-stellate hairs, the ultimate axes (pseudopedicels) very short, to $0.2 \mathrm{~mm}$ long, and flowers congested; bracts $0.6-1.5 \times 0.2-0.6 \mathrm{~mm}$ (but probably also larger), not involucrate, triangular to narrowly triangular, with acute apex, \pm deciduous, with globularstellate hairs; bracteoles $0.4-0.6 \times 0.15-0.4 \mathrm{~mm}, \pm$ triangular, with acute apex, \pm deciduous, with few globularstellate hairs. Flowers not seen, but the following floral characters assessed from slightly immature fruits; 4-merous, \pm sessile; hypanthium 1.8-2 mm long, terete, the free portion $0.3-0.5 \mathrm{~mm}$ long, $1-1.4 \mathrm{~mm}$ wide at the torus, the outer surface with globular-stellate hairs, the inner surface smooth, glabrous, androecial fringe absent; calyx lobes 4 , apically separate, i.e., not calyptrate, the tube $0.17-0.2 \mathrm{~mm}$ long, not tearing between lobes, the lobes $0.15-0.2 \times 0.5-0.6 \mathrm{~mm}, \pm$ triangular, the apex acute to acuminate, abaxially glabrous or with hairs similar to those of hypanthium, and adaxially glabrous; calyx teeth present, 4, each represented by an inconspicuous dorsal bump, 0.1-0.15 mm long, with blunt apex, with sparse globular-stellate hairs; petals, stamens, and style not seen; ovary 2-locular, $3 / 4$ to $2 / 3$ inferior, the apex without a collar or crown, apically glabrous, with axile placentation, the ovules numerous, borne on a placenta that slightly extends into each locule. Berries 1.7-2 mm long, 2-2.3 mm in diameter, globose to subglobose, probably blue, with moderate globularstellate hairs, the hypanthium/calyx not constricted above ovary. Seeds $0.3-0.45 \mathrm{~mm}$ long (slightly immature), angular obovoid, with flat \pm rectangular hilum-raphe region, the testa \pm smooth. See photos in Majure et al. (2014; Fig. 4 A, C, F, G).

Distribution and habitat.-Miconia tetrazygioides is endemic to Hispaniola (Haiti), in the Massif de la Hotte, in often-disturbed moist broadleaved forest over karst limestone (rak bwa) at 930-1300 m.

Specimens examined. HAITI. Departement du Sud: Formón, Bois Cavalier, al sur de Kay Michel, 18¹9'47.2"N, 7401'38"W, 1100 m, 2 Feb 2006, Clase 4161 (FLAS, JBSD); Massif de la Hotte, Macaya Biosphere Reserve, Ville Formon, 8 Jan 2013, Ionta 2023 (FLAS, NY, herbarium of American University of Les Cayes); Massif de la Hotte, Parc National Pic Macaya, ca. $0.5 \mathrm{~km}$ on the Morne Formon side of Sou Bwa (trail between Ville Formon and Sou Bwa), 950-970 m, 1 Jan 1987, Skean $\&$ Lobassiere 2080 (EHH, FLAS, S). The species has only been collected four times since the initial gathering in 1928.

Miconia tetrazygioides is one of 36 taxa of the megadiverse genus Miconia endemic to the Massif de la Hotte, a reduction by one from the number reported in Judd (2019). The La Hotte Mountains are a region of exceptional taxonomic diversity (Judd 1987; Majure et al. 2013; Timyan et al. 2017), especially for Melastomataceae. Many of these species are treated in Liogier (2000).

\section{ACKNOWLEDGMENTS}

We thank Kent Perkins, Collections Manager (FLAS), for assistance in processing and use of specimens. We thank the United States National Herbarium (US) for the loan of an isolectotype of M. tetrazygioides. Other type specimens of this species were accessed via Global Plants on JSTOR. We also thank Ricardo Pacifico, J. Dan Skean, Jr., and an anonymous reviewer for their helpful comments. This research was supported, in part, by National Science Foundation Grant BSR-0818399, and we thank Fabian A. Michelangeli for his administrative and professional assistance in connection with this grant-supported project. 


\section{REFERENCES}

Bécquer, E.R., K.M. Neubig, W.S. Judd, F.A. Michelangelı, J.R. Abbott, \& D.S. Penneys. 2008. Preliminary molecular phylogenetic studies in Pachyanthus (Miconieae, Melastomataceae). Bot. Rev. 74:37-52.

Bécquer, E.R., W.S. Judd, \& L.C. Majure. 2017 (online)/2018 (print). Taxonomic revision of Miconia sect. Calycopteris (Melastomataceae, Miconieae) in Cuba. Brittonia 70:90-110. doi:10.1007/s12228-017-9493-1.

Donoghue, M.J. 1985. A critique of the biological species concept and recommendations for a phylogenetic alternative. Bryologist 88:172-181.

IONTA, G.M., W.S. JudD, J.D. SkeAN, JR., \& C.K. McMullen. 2012. Two new species of Miconia sect. Sagraea (Melastomataceae) from the Macaya Biosphere Reserve, Haiti. J. Bot. Res. Inst. Texas 6:37-44.

Judd, W.S. 1981. A monograph of Lyonia (Ericaceae). J. Arnold Arbor. 62:63-209, 315-436.

JudD, W.S. 1987. Floristic study of Morne La Visite and Pic Macaya National Parks, Haiti. Bull. Florida State Museum, Biol. Sci. 32(1): 1-136.

Judd, W.S. 2007. Revision of Miconia sect. Chaenopleura (Miconieae, Melastomataceae) in the Greater Antilles. Syst. Bot. Monogr. 81:1-235.

Judd, W.S. 2019. Miconia rufinervis (Melastomataceae: Miconieae), an enigmatic endemic of the Massif de la Hotte, Haiti. J. Bot. Res. Inst. Texas 13:229-234.

JudD, W.S. \& G. M. IonTA. 2013. Taxonomic studies in the Miconieae (Melastomataceae). X. Revision of the species of the Miconia crotonifolia complex. Brittonia 65:66-95.

Judd, W.S. \& L.C. MAJuRE. 2019. Miconia elaeagnoides: A morphologically distinctive species within the Caribbean Clade of Miconia (Melastomataceae: Miconieae). J. Bot. Res. Inst. Texas 13:387-396.

Judd, W.S., E.R. Bécquer, \& L.C. Majure. 2014a. Taxonomic studies in the Miconieae (Melastomataceae). XI. A revision of Miconia sect. Calycopteris on Hispaniola. Brittonia 66:216-249.

Judd, W.S., E.R. BéCquer, J.D. SkeAN, JR., \& L.C. Majure. 2014b. Taxonomic studies in the Miconieae (Melastomataceae). XII. Revision of Miconia sect. Miconiastrum, with emphasis on the Miconia bicolor complex. J. Bot. Res. Inst. Texas 8:457-491.

Judd, W.S., L.C. Majure, G.M. IontA, \& K.M. Neubig. 2015. Taxonomic studies in the Miconieae (Melastomataceae). XIII. Systematics of Miconia subcompressa, a Hispaniolan endemic comprised of three eco-geographic subspecies. Phytotaxa 197:61-83.

Judd, W.S., G.M. IonTA, \& L.C. MaJure. 2018. Taxonomic studies in the Miconieae (Melastomataceae). XIV. Species of Miconia section Sagraea that occur in the Greater Antilles and additionally in the Lesser Antilles and/or continental regions. J. Bot. Res. Inst. Texas 12:531-547.

Lıogien, A. H. 2000. La flora de la Españiola. Vol. 10. Jardín Botánico Nacional "Dr. Rafael Ma. Moscoso." Instituto Tecnológico de Santo Domingo (INTEC). Santo Domingo, República Dominicana.

MaJuRE, L.C., G.M. IONTA, J.D. SkEAN, JR., \& W.S. Judd. 2013. New records and notes on species from Parc National Pic Macaya, Massif de la Hotte, Haiti, including a new species of Pilea (Urticaceae). J. Bot. Res. Inst. Texas 7:681-691.

MaJure, L.C., W.S. Judd, G.M. IONTA, J.D. SkeAn, JR., K.M. NeubIG, \& E.R. BéCQUer. 2014. Miconia cineana, a new species from the Massif de la Hotte, Haiti, based on morphological and molecular evidence. Syst. Bot. 39:906-914.

Majure, L.C., W.S. Judd, \& F.A. Michelangelı. 2014 (online)/2015 (print). Taxonomic revision of the Greater Antillean Pseudolima clade of Miconia (Miconia sect. Krugiophytum: Miconieae: Melastomataceae). Brittonia 67:11-18. doi:10.1007/s12228-014-9349-x.

Majure, L.C., K.M. Neubig, J.D. Skean, JR., E.R. Bécquer, \& W.S. Judd. 2015. Evolution of the sandpaper clade (Miconieae, Melastomataceae). Int. J. PI. Sci. 176:607-626.

Majure, L.C., E.R. Bécquer, \&W.S. Judd. 2016. Revision of the Lima clade (Miconia sect. Lima, Miconieae, Melastomataceae) of the Greater Antilles. PhytoKeys 72:1-99.

Majure, L.C., J. D. SkeAn, JR., K.M. Neubig, \& W.S. Judd. 2018. Miconia clasei, a new species of Miconia sect. Calycodomatia (Miconieae: Melastomataceae) from the Sierra de Bahoruco, Dominican Republic and a closer look at species relationships in the sandpaper clade. Syst. Bot. 43:430-438.

Michelangeli, F.A., W.S. Judd, D.S. Penneys, J.D. Skean, JR., E.R. Bécquer, R. Goldenberg, \& C.V. Martin. 2008. Multiple events of dispersal and radiation of the tribe Miconieae (Melastomataceae) in the Caribbean. Bot. Rev. 74:53-77.

Michelangeli, F.A., R. Goldenberg, F. Almeda, W.S. Judd, E.R. Bécquer, G. Ocampo, G.M. Ionta, J.D. Skean, Jr., L.C. Majure, \& D.S. PENNEYs. 2018 (online)/2019 (print). Nomenclatural novelties in Miconia (Melastomataceae: Miconieae). Brittonia 71:82-121. doi 10.1007/s12228-018-9546-0. 
PenNeYS, D.S. \& W.S. Judd. 2005. A systematic revision and cladistic analysis of Charianthus (Melastomataceae) using morphological and molecular characters. Syst. Bot. 30:559-584.

SkEAN, J.D., JR., W.S. Judd, L.C. MajuRE, \& G.M. IontA. 2018. Recognition of Miconia sect. Sagraeoides (Melastomataceae: Miconieae) and associated nomenclatural changes. Brittonia 70:342-355.

MisHLER, B.D. 1985. The morphological, developmental, and phylogenetic basis of species concepts in bryophytes. Bryologist 88:207-214.

Timyan, J.C., W.S. Judd, K.D. Perkins, \& N.H. Williams. 2017. Flora of Macaya National Park, Haiti. A Museum Voices Site, Florida Museum of Natural History. www.floridamuseum.ufl.edu/museum-voices/macaya/.

Urban, I. \& E.L. Ekman. 1929. Miconia tetrazygioides (Melastomataceae). In: I. Urban. Planta Haitienses et Domingenses novae vel rariores VII. a cl. E.L. Ekman 1924-1928 lectae. Ark. Bot. 22A(17):37.

Wheeler, Q.D. \& N.L. PLAtnick. 2000. The phylogenetic species concept (sensu Wheeler and Platnick). In: Q.D. Wheeler \& R. MeIER, eds. Species concepts and phylogenetic theory. Columbia University Press, New York, U.S.A. 